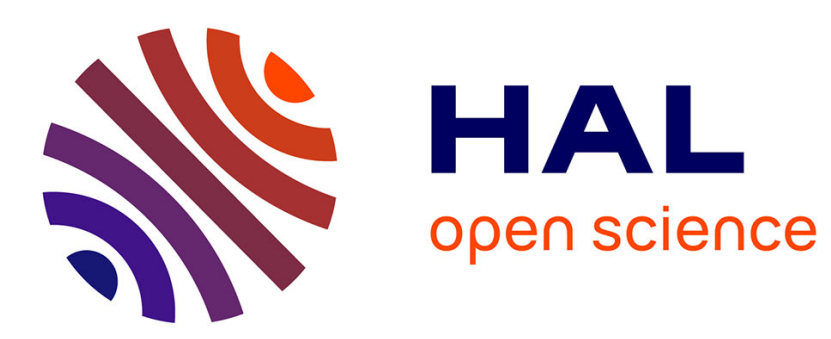

\title{
Ferromagnetic Characteristics of a Perovskite Type of (La, Sr)MnO3 Films Deposited by Kr Sputtering
}

\author{
N. Matsushita, K. Noma, S. Nakagawa, M. Naoe
}

\section{To cite this version:}

N. Matsushita, K. Noma, S. Nakagawa, M. Naoe. Ferromagnetic Characteristics of a Perovskite Type of (La, Sr)MnO3 Films Deposited by Kr Sputtering. Journal de Physique IV Proceedings, 1997, 07 (C1), pp.C1-629-C1-630. 10.1051/jp4:19971259 . jpa-00254967

\section{HAL Id: jpa-00254967 https://hal.science/jpa-00254967}

Submitted on 1 Jan 1997

HAL is a multi-disciplinary open access archive for the deposit and dissemination of scientific research documents, whether they are published or not. The documents may come from teaching and research institutions in France or abroad, or from public or private research centers.
L'archive ouverte pluridisciplinaire HAL, est destinée au dépôt et à la diffusion de documents scientifiques de niveau recherche, publiés ou non, émanant des établissements d'enseignement et de recherche français ou étrangers, des laboratoires publics ou privés. 


\title{
Ferromagnetic Characteristics of a Perovskite Type of (La, $\mathrm{Sr}) \mathrm{MnO}_{3}$ Films Deposited by Kr Sputtering
}

\author{
N. Matsushita, K. Noma, S. Nakagawa and M. Naoe \\ Department of Physical Electronics, Tokyo Institute of Technology, 2-12-1 O-okayama, Meguro, \\ Tokyo 152, Japan
}

\begin{abstract}
La}_{1-\mathrm{x}} \mathrm{Sr}_{\mathrm{x}} \mathrm{MnO}_{3}$ films about $4000 \AA$ thick were deposited by sputtering from the targets with composition of $\mathrm{La}_{0.76} \mathrm{Sr}_{0.24} \mathrm{Mn}_{0.78} \mathrm{O}_{3.0-y}$ in the gas mixture of $\mathrm{Kr}$ and $\mathrm{O}_{2}$. Although the orientation of (110) in which metallic ions are most closely packed was preferential for films deposited in the gas mixture of $\mathrm{Ar}$ and $\mathrm{O}_{2}$, the orientation of (111) in which large ions such as $\mathrm{O}^{2-}, \mathrm{La}^{3+}$ and $\mathrm{Sr}^{2+}$ are most closely packed was also observed in the $\mathrm{X}$-ray diffraction diagrams. The maximum saturation magnetization of the as-deposited films in $\mathrm{Kr}$ and $\mathrm{O}_{2}$ was $0.17 \mathrm{kG}$ and it increased up to $2.4 \mathrm{kG}$ for the film post-annealed at $1000^{\circ} \mathrm{C}$ for 3 hours in oxygen atmosphere. This value was larger than that of the film deposited in $\mathrm{Ar}$ and $\mathrm{O}_{2}$ and annealed under the same condition. It seemed that the recoiled particles to the growing film surface and the atoms incorporated into the film were decreased in sputtering process by using $\mathrm{Kr}$ and therefore, larger $4 \pi \mathrm{M}_{\mathrm{s}}$ was obtained.
\end{abstract}

\section{INTRODUCTION}

Since perovskite oxides such as $(\mathrm{La}, \mathrm{Sr}) \mathrm{MnO}_{3}$ and $(\mathrm{La}, \mathrm{Bi}, \mathrm{Sr}) \mathrm{MnO}_{3}$ possess very attractive properties such as electrical conductivity, ferromagnetism and magneto-optical Kerr effect ${ }^{[1][2]}$, the deposition of perovskite films have also been attempted. However, it has been difficult to prepare highly crystallized films with good magnetic characteristics by sputter-deposition. It seemed to be attributed not only to their complicated crystal struciure, but also the bombardment of the recoiled Ar to the growing film surface. The atomic weight of Ar which is commonly used as sputtering gas, is 39.9 and it is likely to be recoiled by heavy atoms such as $\mathrm{La}$ and $\mathrm{Sr}$ with atomic weights of 138.9 and 87.6, respectively, and they may bombard to the growing film surface and are easily incorporated into the film. Therefore, in this study, heavier noble gas $\mathrm{Kr}$ was used for the deposition of $\mathrm{La}_{1-\mathrm{x}} \mathrm{ST}_{\mathbf{x}} \mathrm{MnO}_{3}$ films and their crystallite orientation and magnetic characteristics were investigated.

\section{EXPERIMENTAL PROCEDURE}

All specimen films were deposited by the facing targets sputtering (FTS) apparatus. This apparatus can confine the discharge plasma in the space between its two facing targets by applying the magnetic field perpendicularly to the target planes, the growing film and the substrate can avoid the plasma damage, i.e., the bombardment of hot- $y$ electrons and negative oxygen ions with high energy ${ }^{[3]}$. Si wafers with thermally oxidized surface layer were used as substrates. Since this surface layer is amorphous and has a very smooth surface, adatoms are able to diffuse on it for a long time and the most closely packed structure is easily formed. A pair of targets with same composition of $\mathrm{La}_{0.76} \mathrm{Sr}_{0.24} \mathrm{Mn}_{0.78} \mathrm{O}_{3-y}$ were prepared by dry ceramic technique. They were pre-sintered from the starting mixture of $\mathrm{La}_{2} \mathrm{O}_{3}, \mathrm{SrCO}_{3}$ and $\mathrm{MnCO}_{3}$ powder at $1000^{\circ} \mathrm{C}$ for 1 hour and $1100^{\circ} \mathrm{C}$ for 2 hour and finally sintered at $1200^{\circ} \mathrm{C}$ for 4 hour. Sintered targets possessed the saturation magnetization $\mathrm{M}_{s}$ of $38.5 \mathrm{emu} / \mathrm{g}$ and it was smaller than $40 \%$ of $\mathrm{M}_{\mathrm{s}}$ of perfect single crystal with same composition (about $100 \mathrm{emu} / \mathrm{g}^{[4]}$ ). The vacuum chamber was evacuated by the diffusion pump and the average background pressure was $8.7 \times 10^{-7} \mathrm{Torr}$. $\mathrm{Kr}$ and $\mathrm{O}_{2}$ gases were introduced independently and total and oxygen gas pressure $P_{\text {total }}$ and $\mathrm{P}_{\mathrm{O}_{2}}$ were in the range of $1.0 \sim 4.0$ and $0.0 \sim$ $0.8 \mathrm{mT}$ Torr, respectively. The substrate temperature $\mathrm{T}_{\mathrm{s}}$ was in the range of $330 \sim 600^{\circ} \mathrm{C}$. DC current supply was used for sputtering and the current was set at constant value of $0.2 \mathrm{~A}$. The discharge voltage was depended on $P_{\text {total }}$ and $P_{\mathrm{O}_{2}}$, and it was in the range from 240 to $330 \mathrm{~V}$. Film thickness was set at about $4000 \AA$.

Film composition was analyzed by the induced coupled plasma spectroscopy(ICPS). Crystallite orientation was evaluated on $\mathrm{X}$-ray diffraction(XRD) diagram and saturation magnetization was measured by using the vibrating sample magnetometer (VSM). 


\section{RESULTS AND DISCUSSIONS}

The orientation of (110) in which metallic ions are most closely packed was preferential for the film deposited in the gas mixture of $\mathrm{Ar}$ and $\mathrm{O}_{2}$. Although each peak intensity became smaller as a whole, the orientation of (111) in which large ions such as $\mathrm{O}^{2-}, \mathrm{La}^{3+}$ and $\mathrm{Sr}^{2+}$ are most closely packed was also preferential for the film deposited in the gas mixture of $\mathrm{Kr}$ and $\mathrm{O}_{2}$ in the X-ray diffraction diagrams as shown in Fig.1. It seemed that, since the network of oxygen ions with very light weight were not so seriously damaged during deposition because the number and energy of recoiled particles were fairly decreased for the deposition in $\mathrm{Kr}+\mathrm{O}_{2}$, (111) orientation could also be observed.

The resistivity of the as-deposited films at room temperature without applied field were in the range from 1.8 to $2.6 \Omega \cdot \mathrm{cm}$ and these value were considerably higher than those of $3-5 \times 10^{-2} \Omega \cdot \mathrm{cm}$ which were reported by other researchers ${ }^{[5][6]}$. Since the crystallinity of the as-deposited films was insufficient and the regular arrangement of $\mathrm{Mn}^{3+}$ and $\mathrm{Mn}^{4+}$ was not fully enough, the as-deposited films showed quite high resistivity.

Figure 2 shows the dependence of saturation magnetization $4 \pi \mathrm{M}_{s}$ on substrate temperature $T_{s}$ for the as-deposited films and the films post-annealed at $1000^{\circ} \mathrm{C}$ for 3 hours in oxygen atmosphere. Although $4 \pi \mathrm{M}_{\mathrm{s}}$ of as-deposited films were almost constant and at most $0.17 \mathrm{kG}$, i.e. about $1 / 30$ of the $4 \pi \mathrm{M}_{\mathrm{s}}$ of the sintered bulk $\mathrm{La}_{0.76} \mathrm{St}_{0.24} \mathrm{Mn}_{1.0} \mathrm{O}_{3-y}$, it increased up to $2.4 \mathrm{kG}$ after the annealing process. Since $4 \pi \mathrm{M}_{\mathrm{s}}$ of the films deposited in $\mathrm{Ar}+\mathrm{O}_{2}$ and annealed at the same conditions was smaller than $1.6 \mathrm{kG}^{[7]}$, it seemed that the decrease of bombardment to the growing film surface and the atoms incorporated into films were fairly decreased by using heavier $\mathrm{Kr}$ and therefore, larger $4 \pi \mathrm{M}_{\mathrm{s}}$ was attained by using $\mathrm{Kr}$ as sputtering gas. However, this value was only half of bulk value and the film surface had irregularities due to excessive growth of crystallites. In addition to that the annealed films had quite high resistivity, almost insulator, due to the cracks of film surface.

Further modifications of deposition conditions, such as use of Xe as sputtering gas, seemed to be required to decrease the preparation temperature and to increase the magnetization.

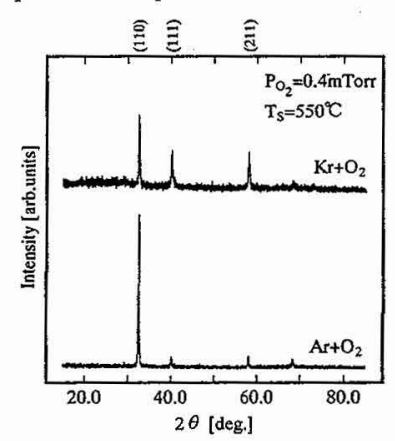

Fig.1 XRD diagrams of $(\mathrm{La}, \mathrm{Sr}) \mathrm{MnO}_{x}$ films as-deposited in $\mathrm{Ar}+\mathrm{O}_{2}$ and $\mathrm{Kr}+\mathrm{O}_{2}$, and schematic illustration of (110) and (111) plane of unit cell.

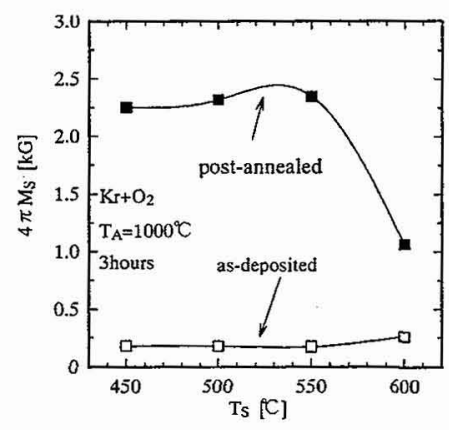

Fig.2 $\mathrm{T}_{\mathrm{s}}$ dependences of $4 \pi \mathrm{M}_{\mathrm{s}}$ of as-deposited films and annealed at $1000^{\circ} \mathrm{C}$ for 3 hours in oxygen atmosphere.

\section{CONCLUSION}

$\mathrm{La}_{1-x} \mathrm{Sr}_{x} \mathrm{MnO}_{3}$ films were sputter-deposited in the gas mixture of $\mathrm{Kr}$ and $\mathrm{O}_{2}$ using FTS apparatus. The orientation of (111) in which large ions such as $\mathrm{O}^{2-}, \mathrm{La}^{3+}$ and $\mathrm{Sr}^{2+}$ are most closely packed was also observed as well as (110) orientation in which metallic ions are most closely packed. The saturation magnetization of the as-deposited films at $550^{\circ} \mathrm{C}$ was at most $0.17 \mathrm{kG}$ and it increased up to $2.4 \mathrm{kG}$ after annealing in oxygen atmosphere. It seemed that the bombardment to the growing film surface and the atoms incorporated into films were fairly decreased by using heavier $\mathrm{Kr}$ and therefore, larger $4 \pi \mathrm{M}_{\mathrm{s}}$ was attained by using $\mathrm{Kr}$ as sputtering gas.

\section{REFERENCES}

[1]J. H. van Santen and G. H. Jonker : Physica, 165, p599 (1950)

[2]T. J. A. Popma and M. G. J. Kamminga : Solid State Communications, 17, p1073 (1975)

[3]M. Naoe, S. Yamanaka and Y. Hoshi : IEEE Trans. Magn., 16, p646 (1980)

[4]M. Imura et. al : Journal of the magnetics society of Japan, 19[2], p245 (1995)

[5]Y. Tomioka and Y. Tokura : Journal of The Magnetics Society of Japan, 19[6], p931-937.

[6]Y. Tokura : OYO BUTURI, 65[3], p230-235

[7]N. Matsushita, K. Noma, S. Nakagawa and M. Naoe : to be published in J. Appl. Phys. in 1996 